Submitted $25^{\text {th }}$ June 2021

Accepted $30^{\text {th }}$ June 2021

\title{
THE INFLUENCE OF EXPERIENTIAL MARKETING ON VISITORS' SATISFACTION AND INTENTION TO REVISIT AT BATUR CAMP BALI
}

\author{
Ni Made Mas Yogiswari ${ }^{1}$, I Gusti Ayu Oka Suryawardani ${ }^{2 *}$ Agung Suryawan \\ Wiranatha $^{3}$ \\ Master Program in Tourism, Udayana University, Indonesia ${ }^{1}$ \\ Centre of Excellence in Tourism, Udayana University, Indonesia ${ }^{2}$ \\ *suryawardani@unud.ac.id ${ }^{2}$
}

\begin{abstract}
Experiential marketing which consists of sense, feel, think, act, and relate is a marketing approach that can generate sensations and experiences, can be used to create tourist satisfaction and become the basis of revisit intention. The purpose of this study is to analyze the influence of experiential marketing to satisfaction and revisit intention. The data in this study were obtained through distributing questionnaires by online to 100 respondents who had experienced on undertook camping at the Batur Camping Ground. Data were analyzed using the SmartPLS based on Structural Equation Modeling (SEM) method. The results showed that sense, feel, act, and relate significantly influence satisfaction. Feel, think, and relate significantly influence revisit intention. Tourist satisfaction significantly influence tourists' intention to revisit. This study suggests that Batur Camping Ground management must improve services in order to keep maintaining tourist satisfaction and increase tourists' decision in undertaking camping.
\end{abstract}

Keywords: experiential marketing, visitor's satisfaction, intention to revisit.

\section{INTRODUCTION}

Camping tourism can be one type of tourism that can be developed well in Bali, one of which is in Kintamani area due to the supportive regional conditions, with its natural beauty. This tourism destination in Bali is also supported by the availability of infrastructure, including an international airport and main road access to various tourism facilities and tourism attractions within the region (Suryawardani et al., 2014). The current type of new normal era tourism can be done by replacing mass tourism with alternative tourism, one of which is ecotourism, where commercial camping tourism is an available option (Samarathunga and Gamage, 2020). The camping site in Kintamani which is one of the latest places visited by domestic tourists is Batur Campground. Knowing the wishes of tourists is something that needs to be considered so that later it is expected to be able to bring in or increase visits and can fulfill the wishes of tourists so that tourists in tourist destinations are satisfied with the products and services provided. Tourist satisfaction is the main goal of the tourism industry (Wiranatha et al., 2016). 
Satisfaction is a complex human process that includes emotional and cognitive processes, along with physical and psychological effects that reflect the individual's sense of positive experience, where after meeting the needs of tourists, destination managers have a strong opportunity to persuade tourists to visit again (Kerdpitak, 2019). Persuading tourists is done with marketing programs to inform and persuade current and potential customers of the value of the product (Suryawardani, 2010).

Experiential marketing is a concept that is considered to be able to create behavioral intention by touching the emotional aspects of tourists and creating positive feelings or impressions on the products offered (Schmitt, 1999). Batur Campground as a tourist destination cannot be separated from the assessment of tourists regarding their experience of camping in that place. The assessment is important to know by the manager, so that they can find out what needs to be improved from the tourism products provided so that tourists are expected to be interested in doing camping again.

The reason for doing this research is that there has not been research related to this topic in the area of Bali, hence research on the influence of experiential marketing on visitors' satisfaction and intention to revisit is urgently needed.

The formulation of the research problem, namely:

a. How is the influence of experiential marketing on tourist satisfaction.

b. How is the effect of experiential marketing on the intention of returning tourists to camp.

c. How is the effect of experiential marketing on the intention of returning tourists to camp through satisfaction.

d. What is the effect of satisfaction on the intention to return to tourists?

Schmitt (1999) with his theory of Strategic Experiential Modules (SEMs) states, SEMs consist of several experiences, namely sensory (sense), feeling (feel), cognitive experience or thinking (think), physical experience and overall lifestyle (act), and experience. obtained through relationships with other communities (relates). Sense marketing deals with the five senses with the aim of creating sensory experiences, through touch, sound, sight, taste and smell. Experience can be viewed as a past activity that occurred in an individual and is stored in the memory of the individual and in experiential marketing a person's experience can be measured more specifically (Hardini et al., 2018). In the research of Tastri et.al (2019), stated that experiential marketing which consists of sense, feel, think, act, relate has an effect on visitor satisfaction and intention to revisit.

According to Kotler and Keller in (Oroh et al., 2015), satisfaction is a person's feelings that arise after comparing perceptions or things expected to the results of a product consumed. If the performance or results of the company obtained are lower than consumer expectations, then consumers are dissatisfied. If performance meets or exceeds expectations, consumers will feel satisfaction. Customer satisfaction creates a good basis for repeat purchases and the creation of 
consumer loyalty, as well as forming a desire for word of mouth recommendations. Research by Widari et.al (2020), shows that tourist satisfaction has a significant effect on tourist loyalty. Satisfaction significantly contributes to their willingness to pay return visits (Purnami and Suryawardani, 2019). If on previous visits tourists are satisfied, then tourists will intend to revisit and vice versa (Aridayanti et al., 2020).

Behavioral intentions (buy back and word of mouth) are expressed as possibilities in determining behavior (Wu et al., 2018). In short, it can be said that revisit intention is related to the consumer's decision to continue the relationship with the service provider in the future. The interest in revisiting is taken from the theory of repurchase interest, where Purchase intention in relation to tourist visits in the purchase of tourism services is referred to as revisit intention (Pujiyati and Sukaatmadja, 2020). The decision process to revisit is formed after the post-visit stage (Hidayana et al., 2019).

\section{METHODOLOGY}

This research was conducted at Batur Campground which consists of Belong Camp, Belong Keliki Camp, Bintang Danu Camp, Jempana Lake side camp located in Kintamani, Bangli Regency, Bali. The research instrument is using a questionnaire, with the determination of the sample is using purposive sampling technique. The respondents used were 100 respondents who were domestic tourists who had camped at Batur Campground. Data was collected through Google Form to visitors who had experience in doing camping in the area of research in Bali. This study uses a quantitative approach and was analyses based on SEM (Structural Equation Modeling) by using SmartPLS program.

The hypotheses in this study are as follow:

The first hypothesis:

$\mathrm{H}_{0} 1$ : Sense has no influence on tourists' satisfaction

$\mathrm{H}_{\mathrm{a} 1}$ : Sense has an influence on tourists' satisfaction

The second hypothesis:

$\mathrm{H}_{02}$ : Feel has no influence on tourists' satisfaction

$\mathrm{H}_{\mathrm{a}}$ : Feel has an influence on tourists' satisfaction

The third hypothesis:

$\mathrm{H}_{03}$ : Think has no influence on tourists' satisfaction

$\mathrm{H}_{\mathrm{a} 3}$ : Think has an influence on tourists' satisfaction

The fourth hypothesis:

$\mathrm{H}_{04}$ : Act has no influence on tourists' satisfaction

$\mathrm{H}_{\mathrm{a} 4}$ : Act has an influence on tourists' satisfaction 
The fifth hypothesis:

$\mathrm{H}_{0} 5$ : Relate has no influence on tourists' satisfaction

$\mathrm{H}_{\mathrm{a} 5}$ : Relate has an influence on tourists' satisfaction

The sixth hypothesis:

$\mathrm{H}_{0} 6$ : Sense has no influence on intention to return to do camping

$\mathrm{H}_{\mathrm{a}} 6$ : Sense has an influence on intention to return to do camping

The seventh hypothesis:

$\mathrm{H}_{0} 7$ : Feel has no influence on intention to return to do camping

$\mathrm{Ha}_{\mathrm{a}}$ : Feel has an influence on intention to return to do camping

The eighth hypothesis:

$\mathrm{H}_{0} 8$ : Think has no influence on intention to return to do camping

$\mathrm{H}_{\mathrm{a}} 8$ : Think has an influence on intention to return to do camping

The ninth hypothesis:

$\mathrm{H}_{0} 9$ : Act has no influence on intention to return to do camping

$\mathrm{H}_{\mathrm{a}}$ : : Act has an influence on intention to return to do camping

The tenth hypothesis:

$\mathrm{H}_{0} 10$ : Relate has no influence on intention to return to do camping

$\mathrm{H}_{\mathrm{a} 10}$ : Relate has an influence on intention to return to do camping

The eleventh hypothesis:

$\mathrm{H}_{0} 11$ : Tourists' satisfaction has influence on intention to return to do camping

$\mathrm{H}_{\mathrm{a} 11}$ : Tourists' satisfaction has an influence on intention to return to do camping

The twelfth

$\mathrm{H}_{0} 12$ : Tourists' satisfaction does not mediate experiential marketing on intention to return to do camping

$\mathrm{H}_{\mathrm{a} 12}$ : Tourists' satisfaction mediates experiential marketing on intention to return to do camping

\section{RESULTS AND DISCUSSION}

\section{Characteristics of Respondents}

The respondents of this study were domestic tourists. In terms of gender, the largest number of respondents were women. Based on regional origin, the majority came from Denpasar City, followed by Tabanan and Giayar Regencies. Based on age, the age range is 20-29. Characteristics of tourists based on the highest 
occupation, namely self-employed. Sources of information on campsites, predominantly sourced from social media and through friends. Based on the characteristics of tourists based on the people who are invited to camp, dominated by respondents who camp with friends, followed by couples, and families.

\section{Validity and Reliability Test Results}

This study uses path analysis techniques for hypothesis testing. Path analysis technique is used to describe and test the relationship model between variables in the form of cause and effect. SEM is able to perform path analysis with latent variables (Ghozali and Latan, 2015). This research was conducted to analyze and test the causal relationship between constructs or latent variables. There are seven latent variables in this study consisting of, sense, feel, act, think. relate, tourist satisfaction, and intention to camp again. The total research indicators are 20 indicators, can be seen in Figure 1

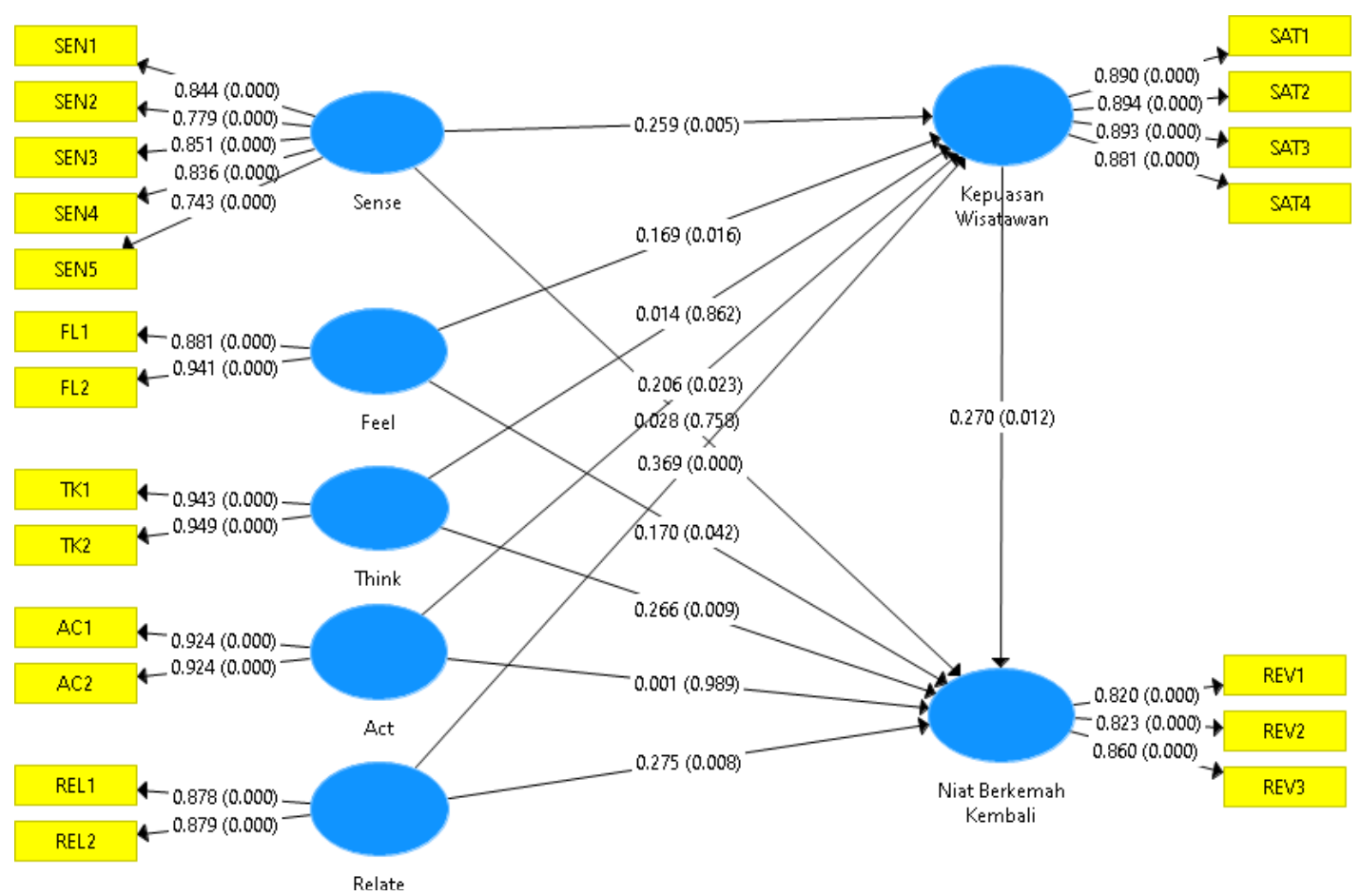

Figure 1. Research Structural Model

Source: data processed with smartpls software

The collected questionnaire data was tested first through validity and reliability tests by looking at the value criteria for convergent validity, discriminant validity and composite reliability. SEM-PLS analysis consists of two sub-models, namely the measurement model or the outer model and the structural model or the inner model.

Validity test can be seen on the value of convergent validity and discriminant validity. Based on Figure 1 of the Research Structural Model, the results of the outer loading can be seen that all indicators reflect the variables of sense, think, act, relate, feel, tourist satisfaction, and intention to return to camping 
with a loading factor value of $>0.70$, and can be declared valid and has meet the convergent validity test. This outer loading value can be used to determine the contribution of each variable. The highest value of outer loading on the indicator of a variable shows that the indicator is strongly correlated with the latent variable.

The model has good discriminant validity if the average variance extracted (AVE) measurement value for each variable is greater than 0.5 (AVE >0.5). Based on Table 1, the average variance extracted (AVE) value of all variables is $>0.5$. The discriminant validity of the indicators can also be seen in the cross loading between the indicators and their constructs. The cross-loading criteria based on the results of this study correlated variables with measurement items greater than the size of other variables, so this indicates that latent variables are able to predict the size of their block better than the size of the other blocks.

The reliability test in the study can be seen from the composite reliability value with the value of $>0.60$. Table 1 shows that the composite reliability value is above 0.60 which means that all variables have met good variable reliability. Another reliability measurement is also seen from the Cronbach's Alpha value, where the Cronbach alpha value is said to be reliable if it exceeds 0.60 . Based on Table 1, it can be seen that the value of Cronbach's Alpha in this study on all variables has a value exceeding 0.60 .

The strength of the relationship between one variable and another can be seen from the value of $\mathrm{R} 2$, where the value is said to be weak if the distance is 0.19 0.32 , moderate if the distance is $0.33-0.66$, and strong if the distance is $>0.67$.

Table 1. Reliability Test Results

\begin{tabular}{|c|c|c|c|c|c|}
\hline Research Variable & $\begin{array}{l}\text { Variable } \\
\text { Type }\end{array}$ & $\begin{array}{l}\text { Average } \\
\text { variance } \\
\text { extracted } \\
\text { (AVE) }\end{array}$ & $\begin{array}{l}\text { Composite } \\
\text { Reliability }\end{array}$ & $\begin{array}{l}\text { Cronbach's } \\
\text { Alpha }\end{array}$ & $R$-square \\
\hline Sense $\left(\mathrm{X}_{1}\right)$ & Exogenous & 0,658 & 0,906 & 0,870 & NA \\
\hline Feel $\left(\mathrm{X}_{2}\right)$ & Exogenous & 0,831 & 0,908 & 0,802 & NA \\
\hline$\overline{\operatorname{Think}\left(\mathrm{X}_{3}\right)}$ & Exogenous & 0,895 & 0,944 & 0,882 & NA \\
\hline $\operatorname{Act}\left(\mathrm{X}_{4}\right)$ & Exogeneous & 0,854 & 0,921 & 0,829 & NA \\
\hline Relate $\left(\mathrm{X}_{5}\right)$ & Exogenous & 0,771 & 0,871 & 0,704 & NA \\
\hline Tourist & Endogenous & 0,791 & 0,938 & 0,912 & \\
\hline Satisfaction $\left(\mathrm{Y}_{1}\right)$ & & & & & 0,752 \\
\hline Recamping & Endogenous & 0,697 & 0,873 & 0,783 & \\
\hline Intention $\left(\mathrm{Y}_{2}\right)$ & & & & & 0,778 \\
\hline Avarage & & 0,785 & - & - & 0,765 \\
\hline
\end{tabular}

Source: Primary Data (processed), 2021 
The results of the study in table 1 show that the value of R2 on the tourist satisfaction variable is 0.752 which can be interpreted that the variability of the tourist satisfaction variable can be explained by the variability of the feel, sense, think, act, and relate variables, which is 75.2 percent and is said to be strong, while the remaining 24.8 percent is explained by other variables outside the researched. The variable intention to return to camping has an $\mathrm{R} 2$ value of 0.778 which can be interpreted that the variability of the variable intention to return to camping can be explained by the variability of the variables sense, feel, think, act, relate and tourist satisfaction of 77.8 percent and can be said to have a strong influence, while the rest of 22.2 percent is explained by other variables outside the researched.

\section{Model Feasibility Test Results}

To assess the feasibility of the structural equation model as a whole, the Goodness of Fit (GOF) value of the model can be done by referring to the formula introduced by (Tanenhaus in Suryawardani 2018) as follows:

$$
\sqrt{\text { Communality } x R^{2}}=\sqrt{\overline{A V E x R^{2}}}
$$

The GOF value of the model by using the formula is 0.77 , where this value exceeds 0.5 so that the model can be interpreted. SRMR Standardized Root Mean Residual $<0.10$, and the model will be declared very suitable if the value of SRMR (Standardized Root Mean Residual) $<0.08$. Based on table 2, it can be seen that the SRMR value in this study is 0.071 , so the model is said to be feasible to test the research hypothesis.

Table 2. Testing Result of GoF

\begin{tabular}{lll}
\hline & Saturated Model & Estimated Model \\
\hline SRMR & 0,071 & 0,071 \\
\hline NFI & 0,709 & 0,709 \\
\hline
\end{tabular}

Source: Primary Data (processed), 2021

\section{Path Coefficient Estimation}

In the structural model (inner model), the estimated path coefficient is seen through the influence between latent variables, both direct effects, indirect effects, and total effects.

\section{Direct effects}

The direct effect is the effect of exogenous variables to endogenous variables that are directly related without any mediating variable. From the results of the significance test, it can be seen the direction of the relationship of the influence of exogenous variables on endogenous variables. The significance of the path coefficient is seen with a significance level of 5\% ( $p$ value 0.05 ) and the path coefficient value indicates a positive direction. The results of the direct effect significance test are shown in Table 3. 
Tabel 3. Direct effect

\begin{tabular}{|c|c|c|c|c|c|c|c|}
\hline $\begin{array}{l}\text { Hypo } \\
\text { thesis }\end{array}$ & $\begin{array}{l}\text { Var. Eksogenus } \\
\rightarrow \text { Var Endogenus }\end{array}$ & $\begin{array}{c}\text { Koefisien } \\
\text { Jalur }\end{array}$ & $\begin{array}{l}\text { Simpang } \\
\text { an Baku }\end{array}$ & $\begin{array}{c}T \\
\text { Statistics }\end{array}$ & $\begin{array}{c}P \\
\text { Value }\end{array}$ & $\begin{array}{c}\text { Signifik } \\
\text { ansi }\end{array}$ & $\begin{array}{c}\text { hypothesis } \\
\text { statement }\end{array}$ \\
\hline H1 & $\begin{array}{l}\text { Sense } \rightarrow \\
\text { Tourist } \\
\text { Satisfaction }\end{array}$ & 0,259 & 0,092 & 2,801 & 0,005 & $\begin{array}{l}* * \\
\text { (Signific } \\
\text { ant) }\end{array}$ & Accepted \\
\hline $\mathrm{H} 2$ & $\begin{array}{l}\text { Feel } \rightarrow \text { Tourist } \\
\text { Satisfaction }\end{array}$ & 0,169 & 0,070 & 2,407 & 0,016 & $\begin{array}{l}* * \\
\text { (Signific } \\
\text { ant) }\end{array}$ & Accepted \\
\hline $\mathrm{H} 3$ & $\begin{array}{l}\text { Think } \rightarrow \text { Tourist } \\
\text { Satisfaction }\end{array}$ & 0,014 & 0,083 & 0,173 & 0,862 & $\begin{array}{l}\text { ns (non } \\
\text { significa } \\
\text { nt) }\end{array}$ & \\
\hline $\mathrm{H} 4$ & $\begin{array}{l}\text { Act } \rightarrow \text { Tourist } \\
\text { Satisfaction }\end{array}$ & 0,206 & 0,090 & 2,281 & 0,023 & $\begin{array}{l}* * \\
\text { (Signific } \\
\text { ant) }\end{array}$ & Accepted \\
\hline H5 & $\begin{array}{l}\text { Relate } \rightarrow \text { Tourist } \\
\text { Satisfaction }\end{array}$ & 0,369 & 0,074 & 4,954 & 0,000 & $\begin{array}{l}\text { ** } \\
\text { (Signific } \\
\text { ant) }\end{array}$ & Accepted \\
\hline H6 & $\begin{array}{l}\text { Sense } \\
\text { Recamping } \\
\text { Intention }\end{array}$ & 0,028 & 0,093 & 0,308 & 0,758 & $\begin{array}{l}\text { ns (non } \\
\text { significa } \\
\text { nt) }\end{array}$ & Rejected \\
\hline $\mathrm{H7}$ & $\begin{array}{l}\text { Feel } \\
\text { Recamping } \\
\text { Intention }\end{array}$ & 0,170 & 0,083 & 2,038 & 0,042 & $\begin{array}{l}* * \\
\text { (Signific } \\
\text { ant) }\end{array}$ & Accepted \\
\hline $\mathrm{H} 8$ & $\begin{array}{l}\text { Think } \\
\text { Recamping } \\
\text { Intention }\end{array}$ & 0,266 & 0,102 & 2,604 & 0,009 & $\begin{array}{l}* * \\
\text { (Signific } \\
\text { ant) }\end{array}$ & Accepted \\
\hline$\overline{\mathrm{H} 9}$ & $\begin{array}{l}\text { Act } \rightarrow \text { Recamping } \\
\text { Intention }\end{array}$ & 0,001 & 0,090 & 0,014 & 0,989 & $\begin{array}{l}\text { ns (non } \\
\text { significa } \\
\text { nt) }\end{array}$ & Rejected \\
\hline H10 & $\begin{array}{l}\text { Relate } \\
\text { Recamping } \\
\text { intention }\end{array}$ & 0,275 & 0,103 & 2,665 & 0,008 & $\begin{array}{l}* \\
\text { (Signific } \\
\text { ant) }\end{array}$ & Accepted \\
\hline H11 & $\begin{array}{l}\text { Tourist } \\
\text { Satisfaction } \\
\rightarrow \text { Recamping } \\
\text { intention }\end{array}$ & 0,270 & 0,108 & 2,504 & 0,012 & $\begin{array}{l}* * \\
\text { (Signific } \\
\text { ant) }\end{array}$ & Accepted \\
\hline
\end{tabular}

Source: Primary Data (processed), 2021 
Based on table 3, it can be seen that the direct effects research results show that the variables sense, feel, act, and relate have a direct influence on satisfaction. This shows that if the sense, feel, act, and relate increase then tourist satisfaction increases. Think marketing on tourist satisfaction shows an insignificant value, this shows that think does not increase tourist satisfaction. The feel, think, and relate variables have a positive and significant influence on the intention to return to camp. This shows that if feel, think, and relate increase, then camping intention will increase again. The sense and act variables have insignificant values, so this shows that sense and act do not increase tourists' intention to return to camp. The tourist satisfaction variable has a positive and significant effect on the intention to return to camping. The results of the exposure in Table 3 can be seen the accepted and rejected hypotheses in this study.

\section{Indirect Effect and Total Effect}

The indirect effect is the effect of exogenous variables to endogenous variables which is realized through mediating variables, which can be seen in Table 4. The indirect and total effects are obtained by bootstrapping, with the aim of seeing the t-statistic value of the measurement model and obtaining the significance of the relationship between latent variables. Significance was seen with a significance level of $5 \%$ ( $\mathrm{p}$ value $<0.05)$.

Table 4. Indirect effect dan Total Effect

\section{\begin{tabular}{llllll}
\hline Exogenous Mediator Endogenous Standard & $\boldsymbol{T}$ & $\boldsymbol{P}$ & Significance
\end{tabular} Deviation Statistics Value}

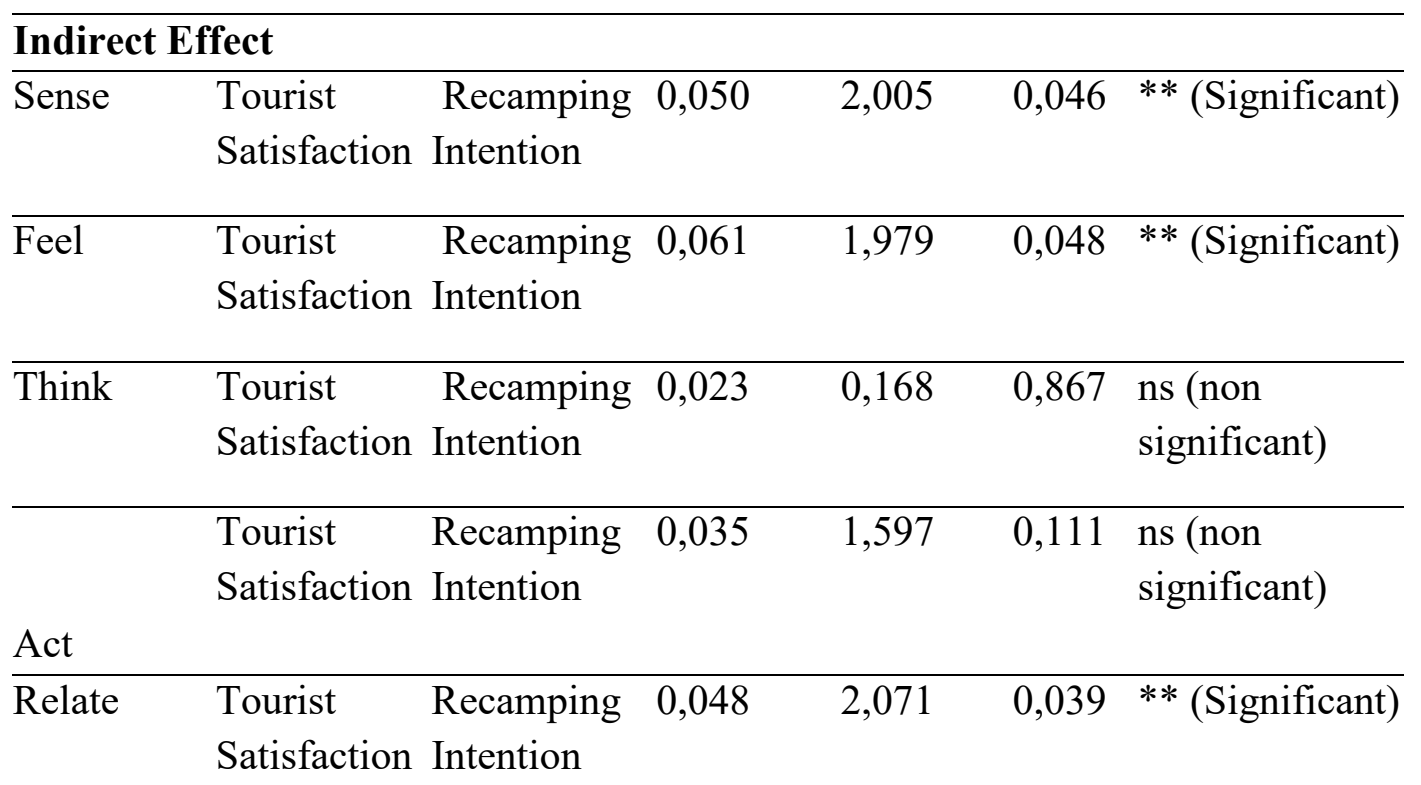




\begin{tabular}{|c|c|c|c|c|c|c|}
\hline \multicolumn{7}{|c|}{ Total Effect } \\
\hline \multirow[t]{2}{*}{ Sense } & - & $\begin{array}{l}\text { Recamping } \\
\text { Intention }\end{array}$ & 0,094 & 1,050 & 0,294 & ns (non \\
\hline & & & & & & significant) \\
\hline Feel & - & $\begin{array}{l}\text { Recamping } \\
\text { Intention }\end{array}$ & 0,085 & 2,542 & 0,011 & $* *$ (Significant) \\
\hline Think & - & $\begin{array}{l}\text { Recamping } \\
\text { Intention }\end{array}$ & 0,103 & 2,623 & 0,009 & ** (Significant) \\
\hline Act & - & $\begin{array}{l}\text { Recamping } \\
\text { Intention }\end{array}$ & 0,079 & 0,722 & 0,471 & $\begin{array}{l}\text { ns (non } \\
\text { significant) }\end{array}$ \\
\hline Relate & - & $\begin{array}{l}\text { Recamping } \\
\text { Intention }\end{array}$ & 0,090 & 4,164 & 0,000 & ** (Significant) \\
\hline
\end{tabular}

Source: Primary Data (processed), 2021

The results of the study stated that the sense, feel, and relate variables had a positive and significant effect on the intention to return to camping with tourist satisfaction as a mediation. Meanwhile, think and act are not significant on the intention to return to camping with tourist satisfaction as a mediation.

The number of direct effects and indirect effects forms the total effect. The significance of the path coefficient is seen with a significance level of 5\% ( $p$ value $<0.05$ ). The results of the total effect significance test can be seen in Table 5. The effect of feel, think, and relate variables on the intention to return to camping with a combination of direct and indirect effects has a positive and significant effect on the intention to return to camp. Meanwhile, sense and act on the intention to recamp again with a combination of direct and indirect effects were not significant on the intention to re-camp again. The value of this path coefficient is obtained from the result of multiplying the outer loading value in Figure 1.

\section{Path Coefficient of Exogenous Variables to Endogenous Variables}

Based on Table 5, it can be seen the comparison of the values of each direct, indirect, and total effect path coefficient in this study. The value of this path coefficient is obtained from the result of multiplying the outer loading value in Figure 1. 
Table 5. Coefficient Value of Direct, Indirect, and Total Effect

\begin{tabular}{llll}
\hline & \multicolumn{3}{c}{ Path Coefficient } \\
\cline { 2 - 4 } & Direct Effect & \multicolumn{1}{c}{ Indirect Effect } & Total Effect \\
\cline { 2 - 4 } $\begin{array}{l}\text { Experiential } \\
\text { Marketing }\end{array}$ & $\begin{array}{l}\text { Experial } \\
\text { Variable }\end{array}$ & & $\begin{array}{l}\text { Experiential } \\
\text { Recamtial }\end{array}$ \\
\hline Sense & 0,028 & $\begin{array}{l}\rightarrow \text { Recamping Intention } \\
\text { Intention }\end{array}$ & \\
\hline Feel & 0,170 & 0,070 & 0,098 \\
\hline Think & 0,266 & 0,046 & 0,216 \\
\hline Act & 0,001 & 0,004 & 0,270 \\
\hline Relate & 0,275 & 0,056 & 0,057 \\
\hline
\end{tabular}

Source: Primary Data (processed), 2021

a. Sense

The path sense coefficient on the intention to camp again in table 5 is 0.028 . Sense of intention to re-camp again through satisfaction (indirect effect) has a path coefficient of 0.070 , this indicates that satisfaction as a mediation affects sense of re-camping intention of 0.070 . Thus, the sense of influencing the intention to return to camp is greater through satisfaction. The sense indicator with the highest outer loading value is SEN 3 (adequately used tents) of 0.851 . The next indicator with a high outer loading value is SEN 4 (the sound of nature being listened to makes calm), SEN 1 (well-organized campsite), SEN 2 (refreshing air in the campsite), and the lowest indicator value is SEN 5 (breakfast served).

b. Feel

The experiential marketing component, namely feel marketing on the intention to return to camping, has a path coefficient value of 0.170 and an indirect effect of 0.046. It can be seen that the feel of making has a greater influence if it is directly related to the intention of returning tourists to camp. The value of the feel marketing path coefficient has a value on the total effect of 0.215 . Camping area security with an outer loading value of 0.881 and a memorable feeling when camping with an outer loading value of 0.941 are indicators of feel marketing by having a significant outer loading value on feel.

c. Think

Based on Table 5, think marketing has a direct effect on re-camping intentions, with a path coefficient value of 0.266 . Satisfaction as a mediating influence of think on the intention to camp again has a path coefficient value of 0.004 . This shows that the direct influence of think on the intention to return to camp is greater than if through satisfaction as a mediating variable. The indicator with the value of outer loading on think marketing can be seen in Figure 1, with a higher value, namely TK 2 (nature tourism becomes more attractive) and followed by TK 2 (camping can make creative thinking). 
d. Act

The marketing act on the intention to return to camping has a path coefficient value of 0.001 . The indirect effect of act has the largest path coefficient value with a value of 0.056 . This shows that the direct effect of act on the intention to return to camp is smaller than if through satisfaction as a mediating variable. Satisfaction as a mediating act on the intention to return to camp can increase its effect, with a total effect value of 0.057 . The value of the act path coefficient on the intention to return to camping has the lowest value among the experiential marketing components. The indicators in the act consist of AC 1 (Freedom to carry out activities in the camp area) and AC 2 (capture the moment by taking pictures) which have a significant outer loading, which can be seen in Fig. Picture 1.

\section{e. Relate}

Based on Table 5, it can be seen that the direct effect of experiential marketing on the intention to camp again has a value of 0.275 and the path coefficient on the indirect effect is 0.100 . It can be seen that relate marketing has a greater direct influence on the intention to return to camp. Relate marketing has the highest path coefficient value among the experiential marketing components, with a value of 0.375 , it can be seen that relate is an experiential marketing component that has a strong influence on increasing the intention of returning tourists to camp. Relate marketing in this study is concerned with increasing tourists' understanding of back to nature tourism and increasing intimacy with invited relatives.

\section{CONCLUSION}

Experiential marketing which consists of sense, feel, act, and relate has a significant effect on tourist satisfaction at Batur Campground, Bali. Experiential marketing which consists of feel, think, and relate has a significant effect on tourists' intention to return to camping at Batur Campground, Bali. Tourist satisfaction has a significant effect on the intention of returning tourists to the Batur Campground, Bali. Most of variables of experiential marketing which consists of sense, feel, and relate have a significant effect on tourists' intention to return to do camping through mediation of tourists' satisfaction, however act and relate has no effect on tourists' satisfaction and returning to do camping.

\section{ACKNOWLEDGMENT}

The author would like to thank Dr. Ir. I Gusti Ayu Oka Suryawardani, M.Mgt., Ph.D., as the first supervisor and Ir. A A. Putu Agung Suryawan Wiranatha, M.Sc., Ph.D., as second supervisor, who patiently provided guidance and advice in the preparation of this thesis from beginning to the end. Greetings to the examiners, Prof. Dr. I Komang Gde Bendesa, M.A.D.E., Prof. Dr. I Made Antara, MS., and Dr. I Putu Gde Sukaatmadja, SE., MP., who has corrected and provided suggestions for the improvement of this thesis. To the administrative staff of the Master Program in Tourism who have helped in launching the lecture process. 


\section{REFERENCES}

Aridayanti, D. A. N., Suryawardani, I. G. A. O., dan Wiranatha, A. S. (2020). Millennial Tourists in Bali: Motivation, Satisfaction and Revisit Intention. E-Journal of Tourism, vol.7. no.1, pp.27- 36.

Dewanthi, P. A. A., dan Wulandari, N. M. (2017). Peran Kepuasan Konsumen Dalam Memediasi Pengaruh Experiental Marketing Terhadap Loyalitas Konsumen. E-Jurnal Manajemen Unud, vol.6, no.1, pp.1-31.

Dewi, L. P. T. A., Wiranatha, A. S., dan Suryawardani, I. G. A. O. (2021). Service Quality, Brand Attributes, Satisfaction and Loyalty of Guests Staying at Le Meridien Hotel Bali Jimbaran. E-Journal of Tourism, vol.8, no.1, pp.97114.

Dhani, N. M., dan Firman. (2015). Pengaruh Experiential Marketing Terhadap Minat Kunjung Ulang Wisatawan Kawasan Objek Wisata Lembah Harau Kabupaten Lima Puluh Kota. Jurnal Praktik Bisnis, vol.4, no.2, pp.159170.

Eka, M. R., dan Yuliana, E. (2016). Pengaruh Experiential Marketing Terhadap Kepuasan Pelanggan (Studi Pada Wiki Koffie Bandung). E-Proceeding of Management, vol.3, no.1, pp.248-255.

Ekoputra, A., Hartoyo, dan Nurrochmat, D. (2017). The Effect of Experiental Marketing on Customer Satisfaction and Loyalty Restaurant 150 Eatery in Bogor. International Journal of Science and Research (IJSR), vol.6, no.9, pp.267-271.

Febrini, I. Y., Widowati, R., dan Anwar, M. (2019). Marketing Kepuasan Konsumen Dan Minat Beli Ulang Di Warung Kopi Klotok, Kaliurang, Yogyakarta. Jurnal Manajemen Bisnis, vol.10, no.1, pp.35-54.

Hardini, W., Bendesa, I. K. G., dan Suryawardani, I. G. O. (2018). International Journal of Multidisciplinary Educational Research-The Study of Experience Economy Toward Tourisit Memorable Experience in Upscale Restaurant, vol.7, no.6 (2), pp.1-16.

Hidayana, F. F., Suryawardani, I. G. A. O., dan Wiranatha, A. S. (2019). The Influence of Tourists' Motivation on Intention to Revisit at The Traditional Village of Prai Ijing, Waikabubak, West Sumba, East Nusa Tenggara. EJournal of Tourism, vol.6, no.2, pp.303-321.

Hutasoit, A. H., Experience, F., dan Konsumen, K. (2020). Pengaruh Sense Experience Dan Feel Experience Terhadap Kepuasan Konsumen Pada Hotel Grand Antares Medan. Jurnal Wira Ekonomi Mikroskil: JWEM, vol.10,no.01, pp.13-20.

Jamu, M. E., dan Laga, Y. (2020). Pengaruh Experiential Marketing Dan Tourist Satisfaction Terhadap Revisit Intention Tourism Di Danau Kelimutu. Jurnal Manajemen Bisnis Krinadwipayana, vol.8, no.1.

Kerdpitak, C. (2019). The Relationship between Hotel Guests' Satisfaction and Revisit Intentions in Bangkok, Thailand. International Journal of Innovation, Creativity and Change, vol.10, no.1, pp.137-156.

Khan, Mahmood. (2017). Hospitality Marketing and Consumer Behaviour 
(creating Memorable Experiencies). USA: Apple Academic Press.

Megawati, Y., dan Novita. (2016). Pesona Kenangan Yang Tak Terlupakan Melalui Pemasaran Berbasis Pengalaman Ala Ahadiat Hotel dan Bungalow, Bandung Yenli Megawati. Journal of Business and Applied Management, vol.9, no.2, pp.172-188.

Nurindasari, R. D., Budiwati, H., dan Irwanto, J. (2020). Pengaruh Dimensi Tourism Experience Terhadap Kepuasan Wisatawan Pada Destinasi. Journal of Organization and Business Management, vol.2, no.3, pp.190193.

Oroh, S., Mananeke, L., and Sangkaeng, S. (2015). Pengaruh Citra, Promosi Dan Kualitas Pelayanan Objek Wisata Terhadap Kepuasan Wisatawan Di Objek Wisata Taman Laut Bunaken Sulawesi Utara. Jurnal Riset Ekonomi, Manajemen, Bisnis Dan Akuntansi, vol.3, no.3, pp.1089-1100.

Patricia, T.C., I G. A. O. Suryawardani, I K. Suamba and Agung Suryawan Wiranatha. (2020). Farmers' Capacity for Jatiluwih Agrotourism Management and Its Effects on Tourists' Satisfaction and Intention to Revisit. E-Journal of Tourism, Vol.7, no.1, pp. 1-15. P-ISSN: 2541-0857, e-ISSN: 2407-392X.

Prasetyo, D. W., dan Wasis. (2019). Pengaruh Experiental Marketing terhadap loyalitas konsumen dan dimediasi oleh kepuasan konsumen Pendahuluan. Management and Business Review, vol.3, no.2, pp.71-82.

Purnami, N.N.A., dan I G. A. O. Suryawardani. (2018). The Effect of the Quality of Services on the Visitors, Satisfaction and Desire to Pay a Revisit to the Bali Pulina Agrotourism. E- Journal of Tourism, 5(2) September, p: 62-71. P-ISSN: 2541-0857, e-ISSN: 2407-392X.

Putri, K. C., Rusminah, dan Furkan, L. M. (2020). Pengaruh Experiential Marketing Terhadap Minat Berkunjung Ulang Kon- sumen Mcdonald's Sriwijaya. Elastisitas - Jurnal Ekonomi Pembangunan Universitas Mataram, vol.2, no.1, pp.100-123.

Pujiyati, H., and Sukaatmadja, I. P. G. (2020). Anteseden Minat Berkunjung Kembali Wisatawan Spiritual di Bali (The Antecedent of Spiritual Tourist Revisit Intention in Bali). E-Jurnal Manajemen UNUD, vol.9, no.1, pp.2139.

Rahman, Suryawardan, I. G. A. O., dan Wiranatha, A. S. (2019). The Influence of Services' Quality on Intention to Revisit through Mediation of Satisfaction of Visitors at Sasak Sade Village. E-Journal of Tourism, vol.6, no.2, pp.322341.

Samsudin, A., Saerang, D. P. E., dan Worang, F. G. (2016). Analysing the Effects of Destination Image and Tourist Satisfaction on Revisit Intention in Case Bunaken National Park. Jurnal Berkala Ilmiah Efisiensi, vol.16, no.4, pp.23-34.

Samarathunga, W., and Gamage, D. (2020). Alternative Tourism as an Alternate to Mass Tourism during the Post-COVID-19 Recovery Phase: The Case of Sri Lanka. $S A G E$.

Schmitt, B. (1999). Experiential Marketing. Journal Of Marketing Management, 
vol.15, pp.53-67.

Schmitt, B. (1999). Experiential Marketing-Howv to Get Customer to Sense,Feel, Think, Act, Relate to Your Company and Brands.New York:The Free Press.

Soelasih, Y. (2016). Pengaruh Experiential Marketing Dan Citra Merek Terhadap Kepuasan Penumpang Kereta Api Bisnis. MIX: Jurnal Ilmiah Manajemen, vol.6, no.3, pp.387-398.

Souza, L. H. De, Kastenholz, E., dan De, M. D. L. (2018). Relevant dimensions of tourist experiences in unique, alternative person-to-person accommodation - sharing castles, treehouses, windmills, houseboats or house-buses. International Journal of Hospitality dan Tourism Administration, pp.1-32.

Surya, E. D., Aditi, B., dan Saragih, M. G. (2020). The Effect of Experiential Marketing on Customer Loyalty with Satisfaction as an Intervening Variables. Enrichment: Journal of Management, vol.11, no.1, pp.103-108.

Suryawardani, I G.A.O., (2010). Branding strategies for agribusiness enterprises. SOCA (Journal on Socio-Economics of Agricultre and Agribusines, vol.10, no.1, pp. 83-88. ISSN: 1411- 7172.

Suryawardani, I G.A.O., A. S. Wiranatha and P. Christine. (2014). Destination Marketing Strategy in Bali Through Optimizing The Potential of Local Products. E-Journal of Tourism, vol. 3, no.1, pp.35-49. P-ISSN: 2541-0857, e-ISSN: 2407-392X.

Suryawardani, I G. A. O., I K. G. Bendesa, M. Antara, and A. S. Wiranatha. (2014). Tourism Leakage of The Accommodation Sector in Bali. Asean Journal on Hospitality and Tourism, vol13, no.1, pp.1-17. ISSN: 14122073.

Suryawardani, I., \& Wiranatha, A. S. (2016). Strategy prioritization for sustainable tourism in Bali, Indonesia: focusing on local agricultural products Analytical Hierarchy Process (AHP) approach. Journal of ISSAAS (International Society for Southeast Asian Agricultural Sciences), 22(1), 96-110.

Tastri, Y. Y., Rahadhin, M. D., and Triastity, R. (2019). Pengaruh Experiential Marketing terhadap Minat Berkunjung Ulang dengan Kepuasan Pengunjung Sebagai Variabel Mediasi (Survei pada Pengunjung Taman Pelangi Jurug Surakarta) Yeni. Jurnal Ekonomi Dan Kewirausahaan, vol.19, no.1, pp.92-105.

Wibisono, N., dan Yahya, E. S. (2019). The Role of Experiential Marketing Towards Satisfaction and Re- Intention To Visit A Tourist. Journal of Tourism dan Sports Management (JTSM) SciTech Central Inc., USA, vol.1, no.1, pp.114.

Purnami, N. N. A., and Suryawardani, I. G. A. O. (2018). The Effect of the Quality of Services on the Visitors' Satisfaction and Desire to Pay a Revisit to the Bali Pulina Agrotourism. E- Journal of Tourism, vol.5, No. 2, pp.62-71.

Widari, N.N., I G. A. O. Suryawardani, I K. Rantau and Agung Suryawan Wiranatha. (2020). The Roles of Farmers in the Development of Belimbing Village Agrotourism and Its Effect on Satisfaction and Loyalty of Tourists. E-Journal of Tourism, vol 7, no.1, pp. 16-26. P-ISSN: 2541-0857, e-ISSN: 2407-392x.

Wiranatha, A. S., Suryawardani, I. G. A. O., Bendesa, I. K. G., dan Antara, M. 
(2016). Model of Foreign Tourists' Loyalty on Marine Tourism to Visit Bali. International Journal of Multidisciplinary Educational Research, vol.5, no.3(1), pp.1-42.

Wu, H. C., Cheng, C. C., and Ai, C. H. (2018). A study of experiential quality, experiential value, trust, corporate reputation, experiential satisfaction and behavioral intentions for cruise tourists: The case of Hong Kong. ElsevierTourism Management, vol.66, pp.200-220. 